\title{
Penerapan Model Pembelajaran Berbasis Masalah Terhadap Kemampuan Pemecahan Masalah Peserta Didik Kelas VIII SMPN 15 Kendari Pada Materi Pokok Cahaya Dan Alat Optik
}

\author{
Wa Ode Novi Astuti Yasin ${ }^{1)}$, Muhammad Anas ${ }^{2)}$, Luh Sukariasih ${ }^{3)}$ \\ 1)*Mahasiswa Jurusan PendidikanFisika Fakultas Keguruan dan Ilmu Fisika Universitas Halu Oleo \\ ${ }^{2)}$ Jurusan PendidikanFisika Fakultas Keguruan dan Ilmu Fisika Universitas Halu Oleo
}

*Korespondensi Email: waodenoviastuti@gmail.com

\begin{abstract}
Abstrak: Penelitian ini dilatarbelakangi oleh masih banyaknya peserta didik yang hanya menghafal konsep dan kurang mampu menggunakan konsep tersebut dalam kehidupan sehari-hari. Selain itu adanya anggapan dari peserta didik bahwa pelajaran IPA khususnya fisika sulit dipahami sehingga peserta didik cenderung malas dan kurang berminat dalam menerima pelajaran maupun mengerjakan tugas sehingga aktifitas peserta didik dalam kelas tergolong rendah. Untuk mengatasinya maka dipilih model pemebelajaran berbasis masalah karena model pembelajaran berbasis masalah dapat memberikan permasalahan fisika yang erat kaitannya dengan kehidupan sehari-hari sehingga peserta didik dapat mengembangkan kemampuan berpikir kritis dan kemampuan pemecahan masalah. Populasi penelitian ini adalah seluruh peserta didik kelas VIII SMPN 15 Kendari yang terdaftar pada semester genap tahun pelajaran 2018/2019 yang berjumlah 97 orang. Sampel penelitian ini adalah kelas VIII 4 sebanyak 24 peserta didik sebagai kelas eksperimen dan kelas $\mathrm{VIII}_{3}$ sebanyak 24 peserta didik sebagai kelas kontrol yang diambil menggunakan teknik purposive sampling. Instrumen penelitian ini berupa tes kemampuan pemecahan masalah peserta didik yang telah divalidasi dan memenuhi kriteria sebagai tes yang baik. Data penelitian dianalisis secara statistic, deskriptif dan inferensial. Hasil penelitian: 1) gambaran hasil tes awal kemampuan pemecahan masalah peserta didik kelas eksperimen pada materi pokok cahaya yaitu diperoleh nilai rata-rata 13,89 dan standar deviasi 3,33 sedangkan pada kelas kontrol diperoleh nilai rata-rata 12,90 dan standar deviasi 2,32 hasil tes akhir peserta didik kelas eksperimen diperoleh nilai rata-rata 63,01 dan standar deviasi 13,36 sedangkan pada kelas kontrol diperoleh nilai rata-rata 50,46 dan standar deviasi 16,$9 ; 2)$ tidak ada perbedaan yang signifikan antara nilai rata-rata kemampuan pemecahan masalah peserta didik kelas eksperimen dan kelas kontrol berdasarkan nilai signifikan 0,296 lebih besar dari $\alpha=0,05 ; 3$ ) nilai rata-rata hasil tes akhir kemampuan pemecahan masalah peserta didik pada kelas eksperimen lebih tinggi secara signifikan daripada nilai rata-rata hasil tes akhir kemampuan pemecahan masalah peserta didik kelas kontrol berdasarkan nilai signifikan 0,016 lebih kecil dari $\alpha=0,05$; dan 4) nilai rata-rata $\mathrm{N}_{\text {Gain }}$ kemampuan pemecahan peserta didik pada kelas eksperimen lebih tinggi secara signifikan daripada nilai rata-rata $\mathrm{N}_{\text {Gain }}$ kemampuan pemecahan masalah peserta didik kelas kontrol berdasarkan nilai signifikan 0,027 lebih kecil dari $\alpha=0,05$. Berdasarkan hasil penelitian dapat disimpulkan bahwa model pembelajaran berbasis masalah lebih baik digunakan dibandingkan model pembelajaran discovery learning terhadap kemampuan pemecahan masalah peserta didik pada materi cahaya dan alat optik kelas VIII
\end{abstract}

Kata Kunci: Model Pembelajaran Berbasis Masalah; Kemampuan Pemecahan; Masalah Peserta Didik.

Abstract: This research is motivated by the large number of students who only memorize the concept and are less able to use the concept in daily life. In addition there is an assumption from students that science lessons especially physics are difficult to understand so students tend to be lazy and less interested in accepting lessons and doing assignments so that students' activities in class are relatively low. To overcome this, the problem based learning model was chosen because the problem based learning model can provide physical problems that are closely related to daily life so students can develop critical thinking skills and problem solving abilities. The population of this research was all students of class VIII of SMPN 15 Kendari who were registered in the even semester of the 2018/2019 academic year totaling 97 people. The sample of this research is class VIII4 as many as 24 students as the experimental class and class VIII3 as many as 24 students as the control class taken using purposive sampling technique. The research instrument was in the form of a test of students' problem solving abilities that had been validated and fulfilled the criteria as a good test. The research data were analyzed statistically descriptive and 
inferential. The results of the study: 1) an overview of the initial test results of students' problem solving abilities of the experimental class on light subject matter that is obtained an average value of 13,89 and a standard deviation of 3,33 while the control class obtained an average value of 12,90 and a standard deviation 2,32 final test results of experimental class students obtained an average value of 63,01 and a standard deviation of 13,36 while in the control class an average value of 50,46 and a standard deviation of 16,9 were obtained;2) there is no significant difference between the average value of the problem solving ability of students in the experimental class and the control class based on a significant value of 0,296 greater than $\alpha=0,05 ; 3)$ the average value of the final test results of students' problem solving ability in the experimental class is significantly higher than the average value of the results of the final test of the problem solving abilities of the control class students based on a significant value of 0,016 smaller than $\alpha=0,05$; and 4) the average value of $N$-Gain in students 'ability to solve in the experimental class is significantly higher than the average value of $\mathrm{N}$-Gain in students' ability to solve problems based on a significant value of 0,027 less than $\alpha=0.05$. Based on the results of research and discussion it can be concluded that the problem-based learning model is better used than the discovery learning learning model of students' problem solving abilities in light material and optical devices class VIII.

Keywords: Problem Based Learning Model; Breaking Ability; Student Problems

\section{PENDAHULUAN}

Model pembelajaran berbasis masalah (PBL) merupakan model pembelajaran yang menyajikan masalah kontekstual yang kemudian masalah tersebut nantinya akan dipecahkan oleh peserta didik dalam kegiatan kelompok sehingga merangsang peserta didik untuk belajar. Peran guru dalam proses pembelajaran model ini adalah sebagai pembimbing peserta didik dalam melakukan penyelidikan bukan memberikan konsep (Azmi, 2016). Kelebihan dari model pembelajaran berbasis masalah diantaranya yaitu dapat menantang kemampuan peserta didik serta memberi kepuasan untuk menemukan pengetahuan baru, dapat meningkatkan aktivitas peserta didik, dapat mengembangkan kemampuan peserta didik untuk berfikir kritis dan mengembangkan pengetahuan mereka untuk menyesuaikan dengan pengetahuan baru, dapat memberikan kesempatan kepada peserta didik untuk mengaplikasikan pengetahuan yang mereka miliki dalam dunia nyata, serta dapat membangun minat peserta didik untuk secara terus menerus belajar sekalipun belajar pada pendidikan formal berakhir (Nurjannah, 2017).

Berdasarkan permasalah tersebut, diperlukan adanya suatu inovasi baru dalam pembelajaran yang dapat mengajak peserta didik untuk mampu mengembangkan kemampuan berpikir, menganalisa, dan memecahkan masalah, serta menghilangkan anggapan peserta didik bahwa IPA khususnya fisika adalah pelajaran yang sulit. Salah satunya adalah dengan memberikan permasalahan fisika yang erat kaitannya dengan kehidupan sehari-hari sehingga peserta didik akan cenderung berfikir sesuai pengalaman yang mereka alami. Hal ini juga ditunjang oleh peran guru dalam memberikan rangsangan pengetahuan, memancing peserta didik untuk berfikir dan menjadikan peserta didik pelajar aktif. Salah satunya melalui penerapan model pembelajaran berbasis masalah. Model ini dipilih karena model pembelajaran tersebut mendorong peserta didik melakukan pengamatan serta memberikan kesempatan pada peserta didik untuk mengaplikasikan pengetahuan yang dimiliki dalam dunia nyata. Selain itu, melalui penerapan model pembelajaran akan mendorong peserta didik untuk melakukan penyelidikan serta mengkomunikasikan hasil temuannya. Model Pembelajaran berbasis masalah bertujuan agar peserta didik memiliki kemampuan berpikir kritis dan kemampuan pemecahan masalah serta mengembangkan kemampuan mereka untuk membangun pengetahuan sendiri (Trianto, 2007). Hal ini sejalan dengan pendapat Grabowski \& Mccarth pada pembelajaran dengan PBL, dimana peserta didik diperkenalkan kepada permasalahan dunia nyata dan didorong untuk mendalaminya, mengetahui tentang permasalahan tersebut, sehingga peserta didik dapat mengambil kesimpulan sendiri atas situasi yang sedang terjadi dan akhirnya peserta didik dapat menemukan pemecahan untuk masalah tersebut (Destianingsih, 2015).

\section{METODE}

Jenis penelitian ini merupakan penelitian quasi experimental atau eksperimen semu dengan bentuk deskriptif kuantitatif yang menggunakan dua kelas untuk dijadikan obyek penelitian yaitu kelas eksperimen dan kelas kontrol. Penelitian telah dilaksanakan di SMP Negeri 15 Kendari semester Genap Tahun Pelajaran 2018/2019 tepatnya tanggal 2 April sampai dengan tanggal 17 Mei 2019 pada materi pokok Cahaya dan Alat Optik. 
Desain penelitian yang digunakan adalah Non equivalent Control Grup Design yang dilakukan terhadap 2 kelompok yaitu kelas eksperimen dan kelas kontrol. Pada desain ini kelompok eksperimen dan kelompok kontrol tidak dipilih secara random. Instrumen yang digunakan untuk mengukur hasil belajar peserta didik pada materi cahaya dan alat optik yaitu dengan memberikan soal tes kemampuan pemecahan masalah berupa essay test yang terdiri dari 7 soal. Soal tes yang diberikan kepada peserta didik kelas eksperimen sama dengan tes yang diberikan kepada peserta didik kelas kontrol. Hasil tes kemudian dianalisis menggunakan dua teknik analisis statistik yaitu analisis deskriptif dan analisis inferensial. Untuk analisis inferensial menggunakan bantuan software SPPS versi 16 .

\section{HASIL DAN PEMBAHASAN}

Peningkatan nilai kemampuan pemecahan masalah peserta didik pada tes akhir dapat dilihat pada gambar berikut.

\section{Diagram Peningkatan Kemampuan Pemecahan Masalah}

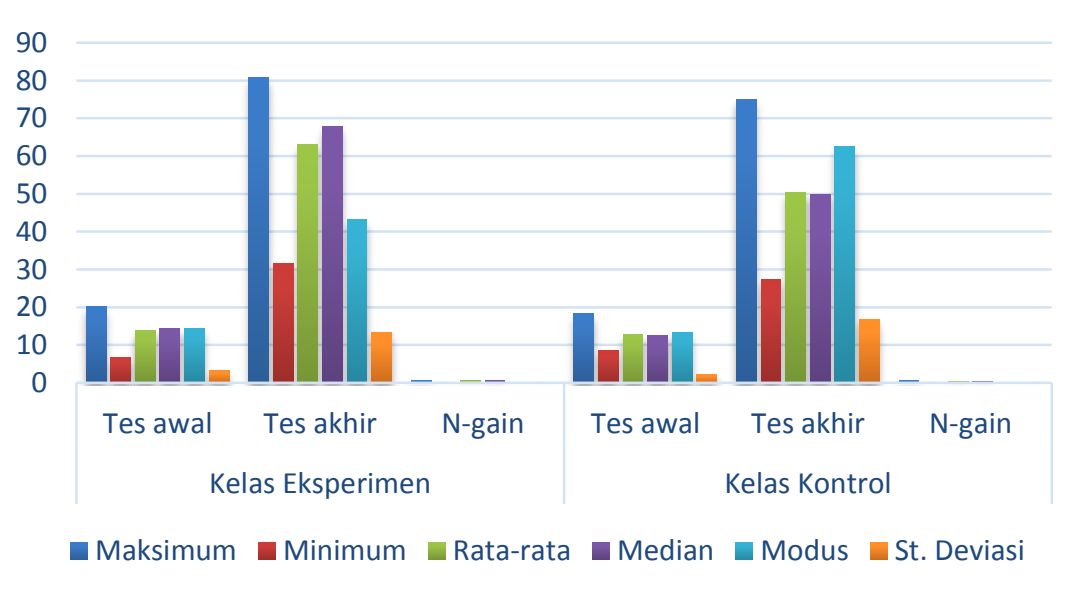

Gambar 1. Deskriptif Peningkatan Kemampuan Pemecahan Masalah

Pengkategorian N-gain (peningkatan) kemampuan pemecahan masalah peserta didik pada kelas eksperimen dan kelas kontrol dapat dilihat pada Tabel berikut.

Tabel 1. Pengkategorian Data N-gain Kemampuan Pemecahan Masalah Peserta Didik Pada Kelas Eksperimen dan Kelas Kontrol

\begin{tabular}{llllll}
\hline \multirow{2}{*}{ Interval Nilai } & \multirow{2}{*}{ Keterangan } & \multicolumn{2}{l}{ Kelas Eksperimen } & \multicolumn{2}{l}{ Kelas Kontrol } \\
\cline { 3 - 6 } & & \multicolumn{2}{l}{ N-gain } & \multicolumn{3}{l}{ N-gain } \\
\cline { 3 - 6 } & Tinggi & 3 & $\%$ & 15,79 & \\
\hline $0,70<$ N-gain & Sedang & 15 & 78,95 & 11 & 5,26 \\
\hline $0,30 \leq$ N-gain $\leq 0,70$ & Rendah & 1 & 5,26 & 7 & 36,84 \\
\hline N-gain $<0,30$ & & & &
\end{tabular}


Uji Normalitas Data

Tabel 2. Rangkuman Hasil Uji Normalitas Data Kemampuan Pemecahan Masalah Peserta Didik Kelas Eksperimen dan Kelas Kontrol

\begin{tabular}{|c|c|c|c|c|}
\hline Kelas & $\begin{array}{l}\text { Aspek yang } \\
\text { Diuji }\end{array}$ & Asymp.Sig & $\mathrm{A}$ & Ket \\
\hline \multirow{2}{*}{ Eksperimen } & Tes awal & 0,838 & 0,05 & \multirow{4}{*}{$\begin{array}{c}\text { Data terdistribusi } \\
\text { normal }\end{array}$} \\
\hline & Tes akhir & 0,513 & 0,05 & \\
\hline \multirow{2}{*}{ Kontrol } & Tes awal & 0,777 & 0,05 & \\
\hline & Tes akhir & 0,697 & 0,05 & \\
\hline
\end{tabular}

Uji Homogenitas Data

Tabel 3. Rangkuman Hasil Uji Homogenitas Data Kemampuan Pemecahan Masalah Peserta Didik Kelas Eksperimen dan Kelas Kontrol

\begin{tabular}{ccccc}
\hline \multirow{2}{*}{ Variabel } & Aspek yang & \multicolumn{2}{c}{ Signifikansi } & \multirow{2}{*}{ Keputusan } \\
\cline { 2 - 4 } & Diuji & Sig. & Alpha $(\alpha)$ & \multirow{2}{*}{ Data Homogen } \\
$\begin{array}{c}\text { Kemampuan } \\
\text { Pemecahan Masalah }\end{array}$ & Tes awal & 0,303 & 0,05 & \\
\cline { 2 - 4 } & Tes akhir & 0,132 & 0,05 & \\
\cline { 2 - 4 } & N-gain & 0,172 & 0,05 & \\
\hline
\end{tabular}

Uji Hipotesis

Tabel 4. Hasil Pengujian Hipotesis Nilai Tes Awal, Tes Akhir dan N-gain Kemampuan Pemecahan Masalah Peserta Didik terhadap Kelas Eksperimen dan Kelas Kontrol

\begin{tabular}{ccccc}
\hline \multirow{2}{*}{ Variabel } & \multirow{2}{*}{ Aspek yang Diuji } & \multicolumn{2}{c}{ Signifikansi } & \multirow{2}{*}{ Keputusan } \\
\cline { 2 - 4 } & & Probabilitas & Alpha $(\alpha)$ & \\
\hline Kemampuan & H1 & 0,296 & 0,05 & $\mathrm{H}_{0}$ diterima \\
\cline { 2 - 4 } $\begin{array}{c}\text { Pemecahan } \\
\text { Masalah }\end{array}$ & $\mathrm{H} 2$ & 0,016 & 0,05 & $\mathrm{H}_{0}$ ditolak \\
\cline { 2 - 4 } & $\mathrm{H} 3$ & 0,027 & 0,05 & $\mathrm{H}_{0}$ ditolak \\
\hline
\end{tabular}

\section{Pembahasan}

Hasil analisis dapat dilihat bahwa model pembelajaran berbasis masalah dapat meningkatkan kemampuan pemecahan masalah peserta didik. Berdasarkan hasil deskriptif kemampuan pemecahan masalah peserta didik pada tes awal yaitu tidak adanya perbedaan yang signifikan antara nilai rata-rata kelas eksperimen dan kelas kontrol dimana nilai rata-rata yang diperoleh tersebut sangat rendah dan semua peserta didik masuk kedalam kategori gagal yaitu nilai yang diperoleh peserta didik masih di bawah 40 . Selain itu indikator kemampuan pemecahan massalah yang dicapai peserta didik pada tes awal baik pada kelas eksperimen maupun pada kelas kontrol kurang maksimal, dimana sebagian besar peserta didik hanya mampu menjawab soal pada indikator memahami masalah saja sedangkan pada indikator merencanakan pemecahan, melakukan rencana pemecahan dan memeriksa kembali pemecahan belum dapat dijawab oleh peserta didik selain itu ada beberapa nomor yang tidak dijawab oleh peserta didik. Hal ini dikarenakan ketika menjawab soal peserta didik belum mempelajari materi yang di teskan sehingga peserta didik belum mengetahui konsep dan persamaan yang digunakan pada soal tersebut sehingga peserta didik hanya mampu menjawab berdasarkan pemahaman peserta didik dari soal. Nilai standar deviasi yang diperoleh kelas eksperimen dan kelas kontrol rendah dikarenakan sebaran nilai yang diperoleh setiap peserta didik pada kelas eksperimen maupun kelas kontrol pada tes awal nilainya tidak jauh berbeda dengan nilai rata-rata tes awal peserta didik pada kelas tersebut sehingga standar deviasinya kecil pada kelas eksperimen dan kelas kontrol.

Hasil deskriptif memperlihatkan bahwa kemampuan pemecahan masalah peserta didik pada tes akhir yaitu adanya perbedaan yang signifikan antara nilai rata-rata kelas eksperimen dan kelas kontrol. Walaupun hasil yang diperoleh peserta didik pada kelas eksperimen lebih tinggi dibandingkan pada kelas kontrol namun sebagian besar peserta didik pada kelas eksperimen maupun kelas kontrol sudah cukup 
maksimal dalam memecahkan masalah yang terdapat pada soal sampai pada indikator memeriksa kembali pemecahan. Adapun nilai peserta didik yang masih rendah tersebut dikarenakan peserta didik masih kurang dalam pengoperasian matematis dan penjelasan konsepnya masih kurang tepat. Peningkatan kemampuan pemecahan masalah peserta didik pada tes akhir dikarenakan peserta didik sudah mempelajari materi yang diteskan sehingga peserta didik sudah mampu menyelesaikan atau memecahkan permasalahan yang ada pada soal sampai pada indikator memeriksa kembali pemecahan.

Nilai standar deviasi untuk tes akhir pada kelas eksperimen dan kelas kontrol cukup tinggi, dimana nilai standar deviasi yang diperoleh kelas eksperimen dan kelas kontrol tinggi menunjukkan bahwa sebaran nilai yang diperoleh setiap peserta didik pada kelas eksperimen maupun kelas kontrol untuk tes akhir nilainya berbeda jauh dengan nilai rata-rata tes akhir peserta didik pada kelas tersebut sehingga standar deviasi yang diperoleh besar pada kelas eksperimen maupun kelas kontrol.

Hasil deskriptif memperlihatkan bahwa kemampuan pemecahan masalah peserta didik pada nilai $\mathrm{N}$-gain diperoleh adanya perbedaan yang signifikan antara nilai rata-rata $\mathrm{N}$-gain pada kelas eksperimen dan kelas kontrol dimana nilai rata-rata $\mathrm{N}$ gain pada kelas eksperimen lebih tinggi dibandingkan nilai rata-rata $\mathrm{N}$-gain pada kelas kontrol. Selain berdasarkan hasil deskriptif, hasil uji hipotesis menggunakan uji-t juga menunjukkan bahwa ada perbedaan yang signifikan antara nilai rata-rata $\mathrm{N}$-gain peserta didik pada kelas eksperimen dan kelas kontrol dimana nilai signifikansi yang diperoleh lebih kecil dibandingkan dengan nilai . Hal ini menunjukkan bahwa terdapat peningkatan yang lebih tinggi pada tes akhir di kelas eksperimen dibandingkan peningkatan tes akhir pada kelas kontrol. Hal ini dipengaruhi adanya perubahan aktifitas peserta didik yang diperbaiki dalam proses pembelajaran sesuai dengan langkah-langkah model pembelajaran berbasis masalah.

Pertemuan pertama pada fase orientasi peserta didik terhadap masalah dimana, peserta didik masih kesulitan dalam mengidentifikasi masalah yang disajikan guru karena belum terbiasa dalam menghadapi suatu permasalahan fisika, sehingga kemampuan peserta didik dalam menentukan informasi berguna maupun merumuskan permasalahan masih rendah. Peserta didik lebih banyak diam, nanti setelah diarahkan berulang-ulang oleh guru baru ada beberapa peserta didik yang terlihat berani dan bisa mengidentifikasi masalah yang ditampilkan oleh guru. Guru perlu menyederhanakan penyampaian permasalahan agar peserta didik lebih mudah paham dan dapat mengefisienkan waktu yang tersisa. Kemudian pada fase membimbing penyelidikan individu dan kelompok, pada pertemuan pertama masih ada beberapa peserta didik yang agak kesulitan dan terlihat pasif dalam menyusun alat praktikum walaupun guru telah memberikan arahan yang perlu dilakukan peserta didik. Hal ini dikarenakan peserta didik malas membaca prosedur yang terdapat dalam LKPD serta peserta didik belum terbiasa dalam mencari informasi sendiri dari berbagai sumber untuk menemukan solusi sehingga guru perlu membimbing peserta didik dalam menentukan konsep fisika dan mencontohkan langkah-langkah yang dapat mereka gunakan untuk membuktikan hipotesis dalam menyelesaikan permasalahan.

Pada fase mengembangkan dan menyajikan hasil karya, pada pertemuan awal terlihat ada beberapa peserta didik yang kesulitan dalam mengolah data hasil pengamatan dimana beberapa peserta didik masih bingung dalam menjawab pertanyaan yang terdapat pada LKPD berdasarkan hasil percobaan yang telah dilakukan serta peserta didik masih kurang paham dalam merumuskan suatu kesimpulan sehingga guru perlu mengarahkan dan membimbing peserta didik. Pada fase menganalisa dan mengevaluasi proses pemecahan masalah, pada pertemuan pertama beberapa peserta didik belum bisa menghubungkan penemuan konsep yang didapat pada praktikum dengan konsep yang ada dibuku referensi sehingga ketika membuat kesimpulan tidak sesuai masalah yang diberikan, sehingga peneliti kembali menjelaskan kepada peserta didik agar kesimpulan yang didapat sesuai dengan masalah yang diberikan peneliti dan mampu menghubungkan hasil yang diperoleh pada eksperimen dengan konsep yang ada pada buku ataupun referensi lainnya. Selain itu, peserta didik juga terlihat pasif dalam menanggapi hasil yang diperoleh temannya.

Peningkatan kemampuan peserta didik pada fase pembelajaran berbasis masalah ini akan memperbaiki cara berfikir peserta didik menjadi lebih kritis dalam memecahkan maalah yang diberikan sehingga kemampuan pemecahan masalah peserta didik dapat meningkat. Hal ini sesuai dengan pendapat Wheeler (dalam Sumiantari,2019) mengemukakan bahwa PBL dapat melatih kecakapan berpikir tingkat tinggi siswa, sehingga dengan diterapkannya model PBL daya ingat siswa terhadap pembelajaran menjadi lebih permanen karena siswa menemukan sendiri jawaban atas permasalahan yang ditemukannya. Berdasarkan hasil analisis nilai $\mathrm{N}$-gain masih belum maksimal hal ini di 
sebabkan oleh beberapa faktor antara lain faktor perbedaan tingkat intelegensi masing-masing peserta didik, kondisi psikologis peserta didik, maupun kondisi lingkungan pada saat pelaksanaan kegiatan pembelajaran sedang berlangsung. Dari hasil penelitian ini sebagaimana telah dikemukakan sebelumnya, memberikan gambaran bahwa model pembelajaran berbasis masalah dapat memberikan sumbangan yang lebih baik terhadap kemampuan pemecahan masalah peserta didik sehingga dapat dijadikan sebagai wahana untuk mengembangkan kemampuan pemecahan masalah peserta didik dan peserta didik mampu mengaplikasikan dalam kehidupan sehari-hari. Pada akhirnya diharapkan peserta didik menjadi lebih paham terhadap materi pelajaran yang dipelajarinya, sehingga berdampak positif terhadap prestasi belajar serta kemampuan pemecahan masalah peserta didik.

\section{KESIMPULAN}

Tidak terdapat perbedaan yang signifikan nilai pretest kemampuan pemecahan masalah peserta didik antara kelas eksperimen dan kelas kontrol. Kemampuan pemecahan masalah peserta didik yang menerapkan model pembelajaran berbasis masalah lebih tinggi secara signifikan daripada peserta didik yang menerapkan model pembelajaran discovery learning pada tes akhir (posttest). Nilai N-gain kemampuan pemecahan masalah peserta didik yang menerapkan model pembelajaran berbasis masalah lebih tinggi secara signifikan daripada peserta didik yang menerapkan model pembelajaran discovery learning.

\section{DAFTAR PUSTAKA}

Arikunto, S. 2009. Dasar-Dasar Evaluasi Pendidikan Edisi 2. Bumi Aksara. Jakarta.

Azizah, R., Lia, Y., dan Eny, L. 2016. Kemampuan Pemecahan Masalah Melalui Pembelajaran Interactive Demonstration Siswa Kelas X SMA pada Materi Kalor. Universitas Negeri Malang. Malang. Vol 2 (2).

Azmi, M. K., Satutik, R., dan Hikmawati. 2016. Pengaruh Model Problem Based Learningdengan Metode Eksperimen dan Diskusi Terhadap Hasil Belajar Fisika Ditinjau dari Sikap Ilmiah Siswa Kelas X MIPA SMAN 1 Mataram. Universitas Mataram. Mataram. Vol 2 (2). ISSN: 24076902.

Cahyani, H., dan Ririn, W. S. 2016. Pentingnya Peningkatan Kemampuan Pemecahan
Masalah
Melalui Pembelajaran
Berbasis
Masalah untuk Mempersiapkan Generasi
Unggul Menghadapi MEA. UNNES.
Semarang.

Chi, M. T. H., dan Glaser, R. 1985. Problem-Solving Ability dalam R. J. Sternberg (Ed), Human Abilities: An Information-Processing Approach. Freeman. New York.

Destianingsih, E., Abidin, P., dan Ismet. 2015. Pengaruh Model Problem Based Learning terhadap Kemampuan Pemecahan Masalah Peserta Didik pada Pembelajaran Fisika Kelas XI di SMA Negeri 1 Tanjung Lubuk. Universitas Sriwijaya. Sumatera Selatan. ISSN: 2355-7109.

Kodariyati, L., dan Budi, A. 2016. Pengaruh Model PBL terhadap Kemampuan Komunikasi dan Pemecahan Masalah Matematika Peserta Didik Kelas V SD. Universitas Negeri Yogyakarta. Yogyakarta. Vol 4 (1). ISSN: 2338-4743.

Meltzer, D. E. 2002. The Relationsip Between Mathematics Preparation and Conceptual Learning Gains in Physics: Posisible "Hidden Variable" in Diagnostic Pretest Scores. American Journal of Physics. Vol 70 (7).

Musfiqon dan Nurdyansyah. 2015. Pendekatan Pembelajaran Saintifik. Nizamia Learning Center. Sidoarjo. ISBN: 978-602-72376-0-5.

Nisak, K., dan Adha, I. 2017. Pengaruh Penerapan Problem Based Learning

Terhadap Kemampuan Pemecahan Masalah Matematika Siswa. Universitas Indraprasta PGRI Jakarta. Jakarta. Vol 3 (1). ISSN: 2477 2348.

Nurjannah, A. 2017. Pengaruh Model Pembelajaran Berbasis Masalah terhadap Peningkatan Pemecahan Masalah Peserta Didik pada Pembelajaran Fisika di SMPN 1 Pante Ceureumen Aceh Barat. Universitas Islam Negeri Ar-Raniry Darussalam. Banda Aceh.

Nursita., Darsikin., dan Syamsu. 2019. Pengaruh Model Pembelajaran Berbasis Masalah Terhadap Kemampuan Pemecahan Masalah Hukum Newton pada Siswa Kelas X SMA Negeri 4 Palu. Universitas Tadulako. Sulawesi Tengah. Vol 3 (2). ISSN: 23383240.

Pardimin., Sri, A. W., dan Indriyati, E. P. 2007. Analisis Butir Soal Pemecahan Masalah Matematika. Universitas Sarjanawiyata. Yogyakarta. 
Pasaribu, F. Y., dan Winsyahputra, R. 2016. Pengaruh Model Problem Based Learning terhadap Kemampuan Pemecahan Masalah pada Materi Pokok Suhu dan Kalor di Kelas X Semester II SMA SwastaAl-Ulum Medan T.P 2015/2016. Universitas Negeri Medan. Sumatera Utara. Vol 4 (4).

Polya, G. 1973. How to Solve it: A New Aspect of Mathematical Method. University Press. Princeton.

Riyanto, Y. 2009. Paradigma Baru Pembelajaran Sebagai Referensi bagi Pendidik dalam Implementasi Pembelajaran yang Efektif dan Berkualitas. Kencana Prenadamedia Group. Surabaya.

Shoimin, A. 2013. 68 Model Pembelajaran inovatif dalam kurikulum 2013. Ar-Ruzz Media. Yogyakarta.

Sinaga, L., dan Betty, M. T. 2016. Pengaruh Model Pembelajaran Berbasis Masalah terhadap Kemampuan Pemecahan Masalah Siswa pada Materi Pokok Listrik Dinamis di Kelas X Semester II SMA Negeri 2 Binjai T.P 2015/2016. Universitas Negeri Medan. Medan. Vol 2 (4). ISSN: 2461-1247.

Suardani, N. N., Ida, B. J. S., dan Ni, L. P. M. W. 2014. Pengaruh Model Pembelajaran Berbasis Masalah terhadap Kemampuan Pemecahan Masalah dan Keterampilan Proses Sains Siswa. Universitas Pendidikan Ganesha. Singaraja. Vol 4.

Sudjana, N. 2015. Penilaian Hasil Proses Belajar Mengajar. PT Remaja Rosdakarya. Bandung.

Sugiyono, 2012. Metode Penelitian Kuantitatif, Kualitatif, dan R\&D. CV Alfabeta. Bandung. 